OPEN ACCESS

Edited by:

Haitao Shi,

Hainan University, China

Reviewed by:

Shan Yuan,

China Agricultural University, China

Qiannan Wang,

Hainan University, China

${ }^{*}$ Correspondence:

Zhirong Zou

zouzhirong2005@hotmail.com

†These authors have contributed equally to this work.

Specialty section:

This article was submitted to

Plant Physiology,

a section of the journal

Frontiers in Plant Science

Received: 12 August 2016 Accepted: 16 November 2016 Published: 06 December 2016

Citation:

Zhao H, Ye L, Wang Y, Zhou X

Yang J, Wang J, Cao K and Zou Z (2016) Melatonin Increases

the Chilling Tolerance of Chloroplast in Cucumber Seedlings by Regulating Photosynthetic Electron Flux and the Ascorbate-Glutathione Cycle. Front. Plant Sci. 7:1814 doi: 10.3389/fpls.2016.01814

\section{Melatonin Increases the Chilling Tolerance of Chloroplast in Cucumber Seedlings by Regulating Photosynthetic Electron Flux and the Ascorbate-Glutathione Cycle}

\author{
Hailiang Zhao ${ }^{1,2,3 t}$, Lin Ye $\mathrm{Y}^{1,2,3,4 t}$, Yuping Wang ${ }^{5 t}$, Xiaoting Zhou ${ }^{1,2,3}$, Junwei Yang ${ }^{1,2,3}$, \\ Jiawei Wang ${ }^{1,2,3}$, Kai Cao ${ }^{1,2,3}$ and Zhirong Zou 1,2,3* \\ ${ }^{1}$ College of Horticulture, Northwest A\&F University, Yangling, China, ${ }^{2}$ Key Laboratory of Protected Horticultural Engineering \\ in Northwest, Ministry of Agriculture, Yangling, China, ${ }^{3}$ State Key Laboratory of Crop Stress Biology for Arid Areas, Yangling, \\ China, ${ }^{4}$ College of Agricultural, Ningxia University, Yinchuan, Ningxia, China, ${ }^{5}$ Department of Garden Engineering, Gansu \\ Agriculture Technology College, Lanzhou, China
}

The aim of the study was to monitor the effects of exogenous melatonin on cucumber (Cucumis sativus L.) chloroplasts and explore the mechanisms through which it mitigates chilling stress. Under chilling stress, chloroplast structure was seriously damaged as a result of over-accumulation of reactive oxygen species (ROS), as evidenced by the high levels of superoxide anion $\left(\mathrm{O}_{2}^{-}\right)$and hydrogen peroxide $\left(\mathrm{H}_{2} \mathrm{O}_{2}\right)$. However, pretreatment with $200 \mu \mathrm{M}$ melatonin effectively mitigated this by suppressing the levels of ROS in chloroplasts. On the one hand, melatonin enhanced the scavenging ability of ROS by stimulating the ascorbate-glutathione (AsA-GSH) cycle in chloroplasts. The application of melatonin led to high levels of AsA and GSH, and increased the activity of total superoxide dismutase (SOD, EC 1.15.1.1), ascorbate peroxidase (APX, EC 1.11.1.11), monodehydroascorbate reductase (MDHAR, EC 1.6.5.4) dehydroascorbate reductase (DHAR, EC 1.5.5.1), glutathione reductase (GR, EC1 1.6.4.2) in the AsA-GSH cycle. On the other hand, melatonin lessened the production of ROS in chloroplasts by balancing the distribution of photosynthetic electron flux. Melatonin helped maintain a high level of electron flux in the PCR cycle [Je(PCR)] and in the PCO cycle [ $\mathbf{J e}(\mathrm{PCO})]$, and suppressed the $\mathrm{O}_{2}$-dependent alternative electron flux $\mathbf{J a}\left(\mathrm{O}_{2}\right.$-dependent) which is one important $\mathrm{ROS}$ source. Results indicate that melatonin increased the chilling tolerance of chloroplast in cucumber seedlings by accelerating the AsA-GSH cycle to enhance ROS scavenging ability and by balancing the distribution of photosynthetic electron flux so as to suppress ROS production.

Keywords: melatonin, chilling, chloroplast, ascorbate-glutathione cycle, photosynthetic electron flow

\section{INTRODUCTION}

Chilling represents as a very common abiotic stress to greenhouse-grown plants. Chilling-sensitive species, such as cucumber (Cucumis sativus L.), can be severely damaged by exposure to chilling temperatures as a result of loss of membrane integrity and associated reductions in enzyme activity (Heidarvand and Amiri, 2010). At low temperatures, the rates of biological reactions, particular 
of carbon dioxide reduction, are strongly reduced and this slowing limits the sinks for absorbed excitation energy (Allen and Ort, 2001). Therefore, even low irradiances can result in severe photoinhibition at low temperatures (Zhang et al., 2011). Photoinhibition not only decreases the photosynthetic ratio but also induces production of reactive oxygen species (ROS), and these lead to oxygen stress. Membranes can be damaged by excessive ROS, resulting in cell dysfunction such as the depression of membrane transport function and the membraneassociated enzyme activity (Zhan et al., 2014; Zhang et al., 2015a). To enhance plant tolerance to chilling and thus improve crop productivity, application of exogenous substances has been used widely (Shuming et al., 2012; Yang et al., 2015; Han et al., 2016). Transgenic approaches have also been used to achieve the same end (Sato et al., 2011; Bao et al., 2015). One of the exogenous substances trialed is melatonin, and this has been widely used to help organisms cope with stress, including with chilling stress (Zhang et al., 2015b).

Melatonin ( $N$-acety-5-methoxytryptamine) is an indoleamine molecule. It was first found in plants in Dubbels et al. (1995) and Hattori et al. (1995). Since then, a wide range of species containing melatonin have been identified, indeed melatonin has been found in nearly all plant organs and tissues examined (Dubbels et al., 1995; Hattori et al., 1995; Manchester et al., 2000; Burkhardt et al., 2001; Chen et al., 2003; HernándezRuiz et al., 2004; Afreen et al., 2006; Tan et al., 2007a; Murch et al., 2010; Zhao et al., 2011; Arnao and Hernández-Ruiz, 2013, 2014; Shi et al., 2015). In addition to being a growth promoter and rooting agent (Sarrou et al., 2014), melatonin plays an important role in protecting plants from abiotic stress (Arnao and Hernández-Ruiz, 2015; Reiter et al., 2015), including from: UV radiation (Arnao and Hernández-Ruiz, 2014), heavy metals (Tan et al., 2007b), extreme temperatures (Bajwa et al., 2014) and salinity (Li et al., 2012). All these stresses lead to over-production of ROS (Zhang et al., 2015b). Melatonin itself is an effective antioxidant, which directly scavenges ROS and whose metabolite, N1-acetyl-N2formyl-5-methoxykynuramine (AMFK), can also directly and efficiently scavenge ROS (Tan et al., 2007a; Manchester et al., 2015). Beyond this, melatonin also possesses antioxidant activity operating by stimulating antioxidant enzymes and augmenting antioxidants and involving the ascorbateglutathione (AsA-GSH) cycle to scavenge excess ROS (Wang et al., 2012; Li et al., 2015; Chao et al., 2016). However, previous studies on the effects of melatonin on the AsA-GSH cycle under stress conditions are based mainly on whole leaves. Occurrence of ROS has also been reported in cell organelles, in chloroplasts, mitochondria and peroxisomes, and in the cytoplasm (Palma et al., 2006). The effects of melatonin on the AsA-GSH cycle may be different in different parts of a cell. Chloroplasts, being the site of photosynthesis, are also the primary source of ROS. The mechanisms through which melatonin affects the AsA-GSH cycle in chloroplasts are still not clear.

The level of ROS in chloroplasts is not only dependent on ROS scavenging ability but also on the ROS generating rate (Figure 1). The generation of ROS in chloroplasts is affected mainly by the distribution of electron fluxes through photosystem II (Zhou et al., 2004). The electron fluxes can be categorized into three groups: (1) electron fluxes associated with photosynthetic carbon reduction $[J e(P C R)],(2)$ electron fluxes associated with photorespiration $[\mathrm{Je}(\mathrm{PCO})]$ and (3) alternative electron fluxes (Ja) (Miyake and Yokota, 2000; Jiang et al., 2013). One of the last of these is $\mathrm{O}_{2}$-independent $\left[\boldsymbol{J a}\left(\mathrm{O}_{2}\right.\right.$-independent $\left.)\right]$ and the other is $\mathrm{O}_{2}$-dependent $\left[\boldsymbol{J a}\left(\mathrm{O}_{2}\right.\right.$-dependent)] (Miyake and Yokota, 2000, 2001; Peeva et al., 2012). $\boldsymbol{J a}\left(\mathrm{O}_{2}\right.$-dependent) is one important source of ROS and its increase will led to the ebullition of ROS under stress condition (Zhou et al., 2004),. Under stress, $\boldsymbol{J a}\left(\mathrm{O}_{2}\right.$-dependent) fluxes increased dramatically along with a reduction in $\boldsymbol{J} \boldsymbol{e}$ (PCR) (Liu et al., 2012). It has been reported that $\boldsymbol{J a}\left(\mathrm{O}_{2}\right.$-dependent) fluxes can be suppressed by phytohormones such as by brassinosteroids (Jiang et al., 2013). These are similar to one type of phytohormone but whether melatonin has the same function is unknown. Earlier studies show that melatonin can regulate the expressions of the photosystem I genes PsaA, PsaF, PsaG, PsaH, PsaK and PsaO, of the photosystem II genes PsbE, PsbO, PsbP, PsbQ, PsbY, PsbZ and Psb28, and of the Calvin cycle genes rbcS, GAPC1 and GAPCP-2 (Wei et al., 2014). The variation of photosynthesis genes expression may led to changes of the electron fluxes in PSII. Therefore, the role of melatonin in regulating the distribution of electron fluxes in PSII under stress conditions is also worth exploring.

In this study, we determine whether melatonin pretreatment can alleviate chilling stress by regulating ROS levels in chloroplasts of cucumber. As well as exploring the mechanisms through which melatonin affects the AsA-GSH cycle (an important antioxidant system scavenging ROS in chloroplasts) we also explored the role of melatonin in regulating the distribution of electron fluxes in photosystem II (which is largely responsible for the production of ROS in chloroplasts).

\section{MATERIALS AND METHODS}

\section{Plant Material and Treatments}

Seeds of cucumber (Cucumis sativus L.) cultivar Xinyan 4 were planted singly in black plastic pots $(7 \mathrm{~cm} \times 7 \mathrm{~cm})$ filled with mixed nutrient medium (peat: vermiculite: perlite $=2: 1: 1$ ) and placed in a growth chamber under standard conditions $\left[28 / 18^{\circ} \mathrm{C}\right.$ day/night temperatures, $12 \mathrm{~h}$ photoperiod, $300 \mu$ molm $^{-2} \mathrm{~s}^{-1}$ photon flux density and $75 \%$ relative humidity $(\mathrm{RH})]$. From the time the second leaf was fully expanded, the nutrient medium of half the seedlings was irrigated with $10 \mathrm{~mL} 200 \mu \mathrm{M}$ melatonin solution at eight o'clock every night. $0.1856 \mathrm{~g}$ melatonin was firstly solved in $4 \mathrm{~mL}$ ethanol and then dilute with water to $4 \mathrm{~L}$ to get $200 \mu \mathrm{M}$ melatonin - this concentration had been determined in a previous trail (unpublished data) to be quite effective in lowering the ROS level. The rest were irrigated with $10 \mathrm{~mL}$ distilled water contain the same ethanol concentration until the experiment was terminated every day. After 5 days of melatonin treatment, the groups of water- and melatonin-treated seedlings were each randomly divided into 


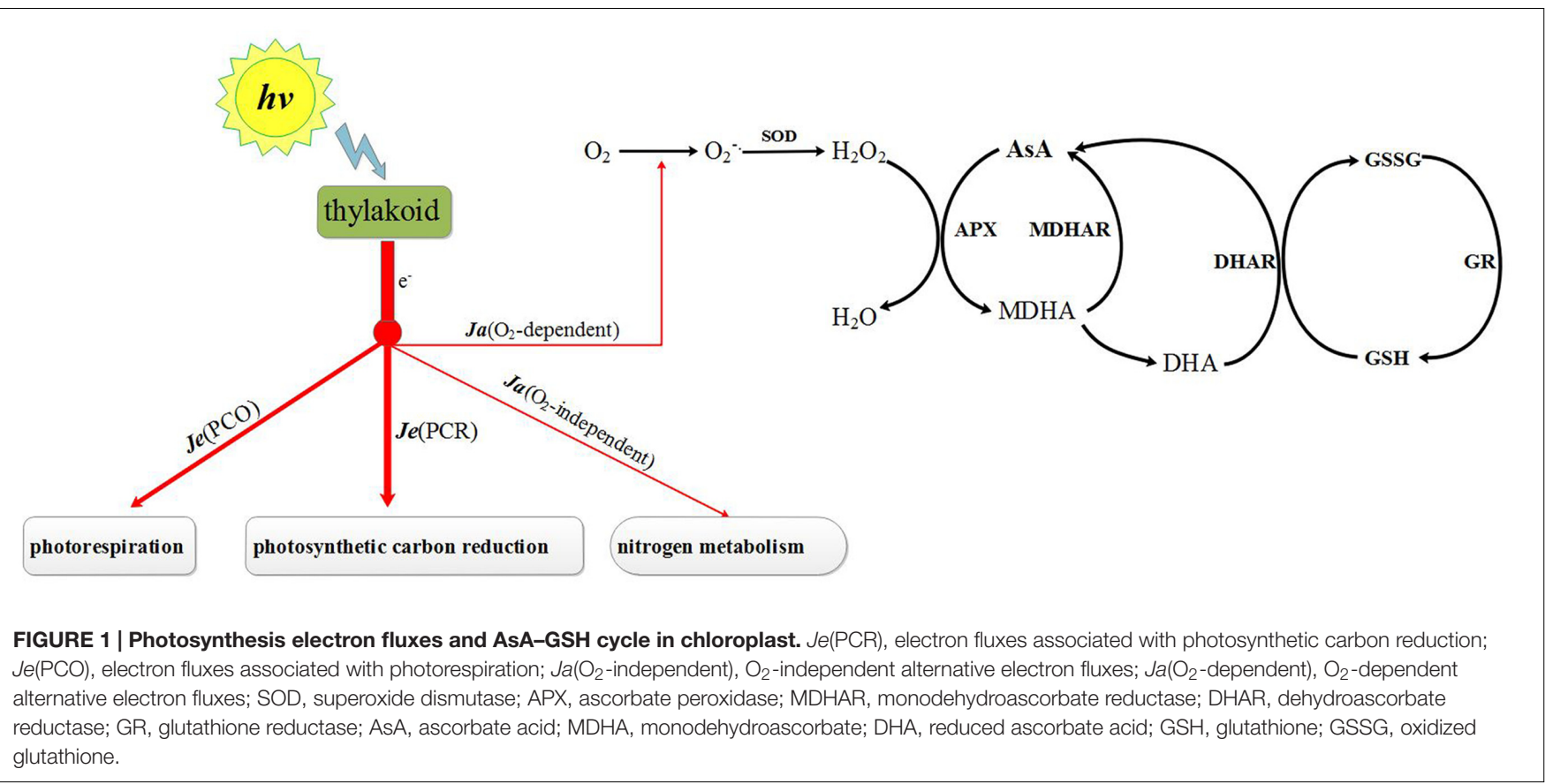

two subgroups. One subgroup of each was moved to another growth chamber with a chilling environment $\left(15 / 8^{\circ} \mathrm{C}\right.$ day/night temperatures, $12 \mathrm{~h}$ photoperiod, $300 \mu \mathrm{molm}^{-2} \mathrm{~s}^{-1}$ photon flux density and $75 \% \mathrm{RH}$ ) while the other two subgroups were grown on under the former standard conditions. This resulted in four different subgroups: (i) Control - grown under standard conditions and irrigated with distilled water, (ii) Control + Melatonin - grown under standard conditions and irrigated with melatonin, (iii) Chilling - grown under chilling conditions and irrigated with distilled water, and (iv) Chilling + Melatonin - grown under chilling conditions and irrigated with melatonin.

Leaf samples were taken from all four subgroups (i, ii, iii, iv), $0,2,4,6$, and 8 days after the chilling treatment was imposed (on subgroups iii and iv). These were rapidly frozen in liquid nitrogen and stored at $-80^{\circ} \mathrm{C}$ pending analysis. Photosynthesis and fluorescence parameters were measured on leaves of all subgroups 4 days after chilling treatment.

\section{Isolation of Chloroplasts}

Intact chloroplasts were isolated according to Robinson et al. (1983) with some modification. Leaves (10 g) were extracted at $0^{\circ} \mathrm{C}$ with $20 \mathrm{~mL}$ of isolation buffer containing $330 \mathrm{mM}$ sorbitol, $30 \mathrm{mM}$ Mes, $2 \mathrm{mM}$ ascorbate and $0.1 \%$ BSA adjusted to $\mathrm{pH} 6.5$ with Tris. The brei was filtered through four layers of cotton wool and centrifuged at $1200 \mathrm{~g}$ for $3 \mathrm{~min}$. After discarding the supernatant, the pellets were re-suspended in $2 \mathrm{~mL}$ of suspension buffer containing $330 \mathrm{mM}$ sorbitol, $30 \mathrm{mM}$ Hepes and $0.2 \%$ BSA adjusted to $\mathrm{pH} 7.6$ with Tris. The suspension was placed in centrifuge tubes containing $3.5 \mathrm{~mL}$ of $80 \%$ percoll and $3.5 \mathrm{~mL}$ of $40 \%$ percoll, and then centrifuged at $1200 \mathrm{~g}$ for $1 \mathrm{~min}$. Intact chloroplasts were found in the intermediate region between $80 \%$ percoll and $40 \%$ percoll.

\section{Analysis of Malonaldehyde (MDA), Superoxide Anion $\left(\mathrm{O}_{2}^{-}\right)$and Hydrogen Peroxide $\left(\mathrm{H}_{2} \mathrm{O}_{2}\right)$ in Chloroplasts}

For the MDA assay, $1 \mathrm{~mL}$ of chloroplast suspension was homogenized with $2 \mathrm{~mL}$ of $10 \%$ TCA and centrifuged at $4000 \mathrm{~g}$ for $10 \mathrm{~min}$. Next, $700 \mu \mathrm{L}$ of the supernatant was incubated at $100^{\circ} \mathrm{C}$ in a boiling water bath for $15 \mathrm{~min}$ with $700 \mu \mathrm{L}$ of $0.6 \%$ thiobarbituric acid (TBA) dissolved in 10\% TCA. The absorptions were measured at 600,532 , and $450 \mathrm{~nm}$. The content of MDA was calculated as described by Heath (Heath and Packer, 1968).

The $\mathrm{O}_{2}^{-}$was assayed as described by Ke et al. (2007) with some modification. First, $675 \mu \mathrm{L}$ of chloroplast suspension was homogenized with $675 \mu \mathrm{L}$ of phosphate buffer $(\mathrm{pH}$ 7.8) and $1 \mathrm{~mL}$ hydroxylamine hydrochloride. The mixture was incubated at $25^{\circ} \mathrm{C}$ for $20 \mathrm{~min}$. Then, $0.375 \mathrm{~mL}$ of $17 \mathrm{mM} \gamma$-aminophenylsulfonic and $0.375 \mathrm{~mL}$ of $7 \mathrm{mM} \alpha$-amino-phenylsulfonic were added to the mixture for another $20 \mathrm{~min}$ of incubation at $30^{\circ} \mathrm{C}$. Next, $3.2 \mathrm{~mL}$ of ether was added to avoid interference from chlorophyll. The absorption of the reaction mixture was measured at $530 \mathrm{~nm}$. $\mathrm{O}_{2}^{-}$was calculated from a standard curve based on sodium nitrite.

Hydrogen peroxide $\left(\mathrm{H}_{2} \mathrm{O}_{2}\right)$ was assayed as described by Sergiev et al. (1997) with some modification. First, $1 \mathrm{~mL}$ of chloroplast suspension was homogenized with $2 \mathrm{~mL}$ of icecold $0.1 \% \mathrm{TCA}$ and centrifuged at $12,000 \mathrm{~g}$ for $15 \mathrm{~min}$. Then, $0.5 \mathrm{~mL}$ of the supernatant was added to $0.5 \mathrm{~mL}$ of $100 \mathrm{mM}$ potassium phosphate buffer $(\mathrm{pH} 7.0)$ and $1 \mathrm{~mL}$ of $1 \mathrm{M} \mathrm{KI}$ and incubated for $1 \mathrm{~h}$ in darkness. Absorbance was measured at $390 \mathrm{~nm}$. The content of $\mathrm{H}_{2} \mathrm{O}_{2}$ was calculated base a standard curve.

To detect $\mathrm{H} 2 \mathrm{O} 2$ production in chloroplast, chloroplasts were incubated in $5 \mu \mathrm{M}$ of $2^{\prime}, 7^{\prime}$-dichlorofluorescein diacetate (DCFH-DA) dissolved in chloroplast suspension buffer for 


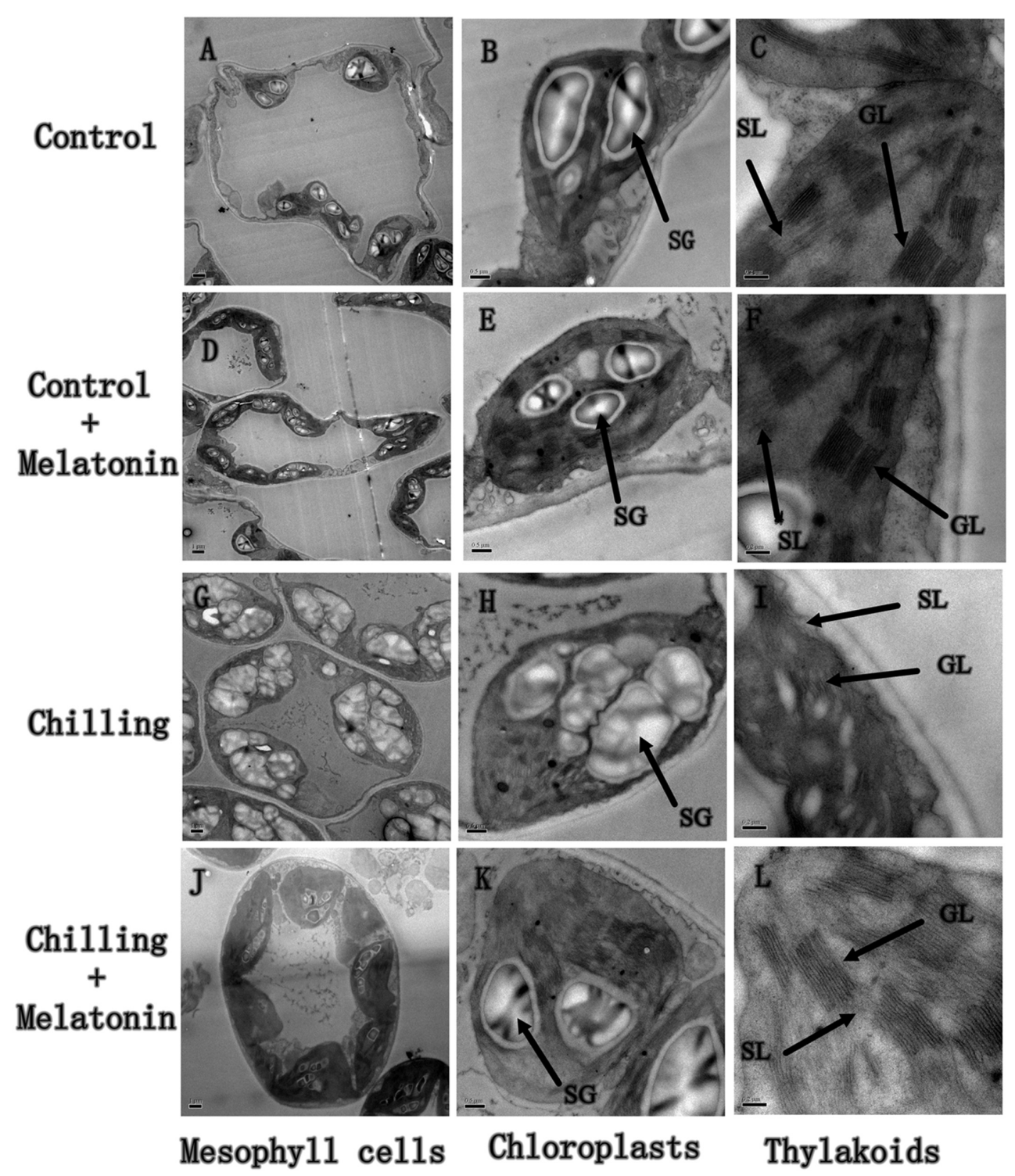

FIGURE 2 | Effects of exogenous melatonin on chloroplast structure under chilling stress. The second, fully expanded leaves were measured after 4 days of chilling. (A-C) Control (28/18 $\mathrm{C})$; (D-F) Control + Melatonin (200 $\mu \mathrm{M}$ melatonin, 28/18 $\mathrm{C})$; (G-I) Chilling $\left(15 / 8^{\circ} \mathrm{C}\right) ;(\mathbf{J}-\mathbf{L})$ Chilling + Melatonin $(200 \mu \mathrm{M}$ melatonin, $\left.15 / 8^{\circ} \mathrm{C}\right)$. SL, stoma lamellae; GL, grana lamellae; SG, starch grains.

$30 \mathrm{~min}$ at $25^{\circ} \mathrm{C}$ under darkness. After washing three times, green fluorescence, indicative of the oxidation by $\mathrm{H}_{2} \mathrm{O}_{2}$ of DCFHDA to $2^{\prime}, 7^{\prime}$-dichlorofluorescin (DCF), was monitored (excitation: $488 \mathrm{~nm}$, barrier: $500-550 \mathrm{~nm})$ in a FV1200 confocal laser scanning microscope (OLYMPUS, Japan).

\section{Analysis of Antioxidant Metabolites in Chloroplasts}

A volume of $300 \mu \mathrm{L}$ of chloroplast suspension was homogenized with $1.2 \mathrm{~mL}$ of ice-cold $6 \%(\mathrm{v} / \mathrm{v}) \mathrm{HClO}_{4}$ and centrifuged at $4{ }^{\circ} \mathrm{C}$ for $10 \mathrm{~min}$ at $10,000 \mathrm{~g}$. The supernatant was used to assay AsA and reduced ascorbate acid (DHA) as described by Wang et al. (2012).
First, $300 \mu \mathrm{L}$ of chloroplast suspension was homogenized with $1.2 \mathrm{~mL}$ of $5 \%$ sulfosalicylic and centrifuged at $4^{\circ} \mathrm{C}$ for $10 \mathrm{~min}$ at $14,000 \mathrm{~g}$. The supernatant was used to assay glutathione (GSH) and oxidized glutathione (GSSG) as described by Wang et al. (2012).

\section{Analysis of Antioxidant Enzymes in Chloroplasts}

A volume of $3 \mathrm{~mL}$ of chloroplast suspension was homogenized with $3 \mathrm{~mL}$ of ice-cold $25 \mathrm{mM}$ Hepes buffer ( $\mathrm{pH}$ 7.8) containing $0.2 \mathrm{mM}$ EDTA and $2 \% \mathrm{PVP}$ and centrifuged at $4^{\circ} \mathrm{C}$ for $10 \mathrm{~min}$ at $13,000 \mathrm{~g}$. The supernatant was used to analyze antioxidant enzyme in chloroplasts. 


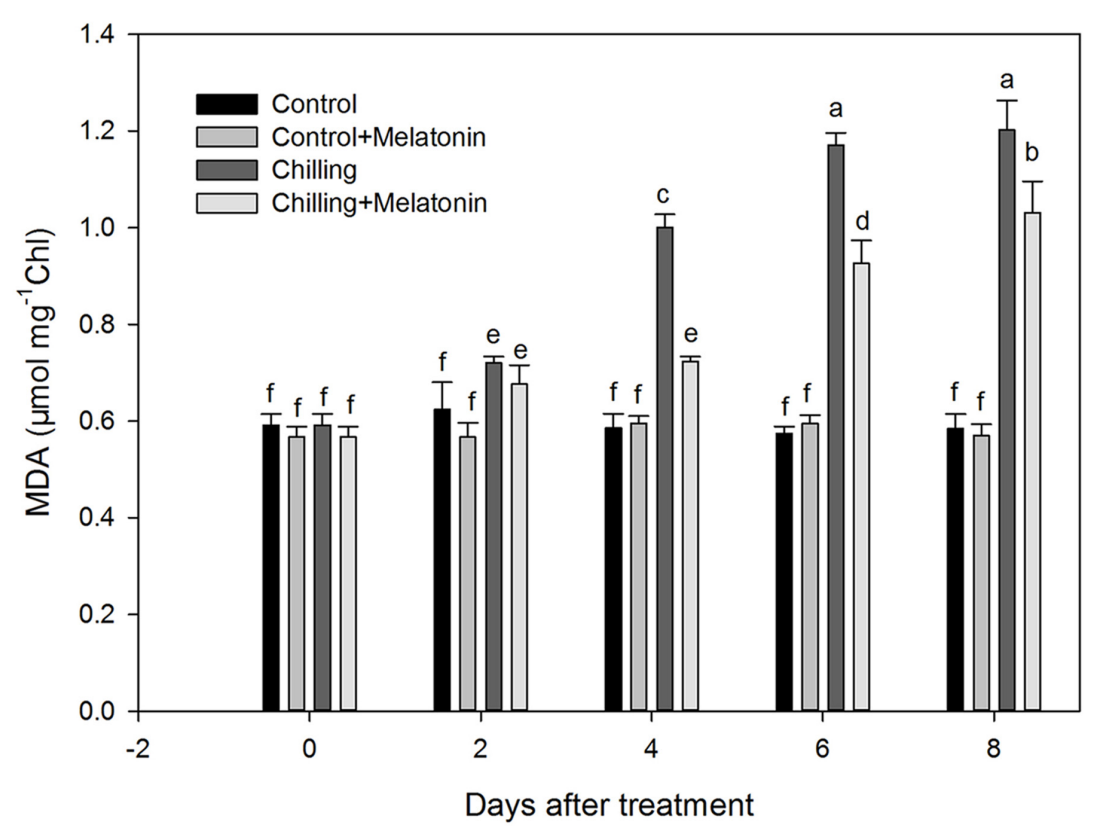

FIGURE 3 | Effects of exogenous melatonin on malonaldehyde (MDA) content of chloroplasts under chilling stress. Control (28/18 $\left.{ }^{\circ} \mathrm{C}\right)$;

Control + Melatonin $\left(200 \mu \mathrm{M}\right.$ melatonin, $\left.28 / 18^{\circ} \mathrm{C}\right)$; Chilling $\left(15 / 8^{\circ} \mathrm{C}\right)$; Chilling + Melatonin $\left(200 \mu \mathrm{M}\right.$ melatonin, $\left.15 / 8^{\circ} \mathrm{C}\right)$. Data are means $\pm \mathrm{SD}$ of three replicates.

Different letters indicate significant differences according to a Duncan's multiple range test $(P<0.05)$.

Total SOD (EC 1.15.1.1) was measured as described by Thayer (1990). One unit of SOD was defined as the amount of enzyme inhibiting $50 \%$ of NBT reduction.

For ascorbate peroxidase (APX, EC 1.11.1.11), the decrease in absorbance at $290 \mathrm{~nm}$ was measured as a result of the oxidation of reduced ascorbate (ASC) (extinction coefficient of $\left.2.8 \mathrm{mM} \cdot \mathrm{cm}^{-1}\right)$. The reaction mixture $(3 \mathrm{~mL})$ contained $50 \mathrm{mM}$ Hepes-KOH (pH 7.6), 0.1 mM EDTA-Na, 0.5 mM ASC, $0.2 \mathrm{mM}$ $\mathrm{H}_{2} \mathrm{O}_{2}$, and $100 \mu \mathrm{L}$ enzyme extract. The reaction was initiated by adding $\mathrm{H}_{2} \mathrm{O}_{2}$ (Logan et al., 1998).

For monodehydroascorbate reductase (MDHAR, EC 1.6.5.4), the decrease in absorbance at $340 \mathrm{~nm}$ was measured following the oxidation of NADH (nicotinamide adenine dinucleotide, reduced) (extinction coefficient of $6.22 \mathrm{mMcm}^{-1}$ ). The reaction mixture $(3 \mathrm{~mL})$ contained $50 \mathrm{mmol} \cdot \mathrm{L}^{-1} \mathrm{~K}$-phosphate buffer (pH 7.3), $0.2 \mathrm{mmol} \cdot \mathrm{L}^{-1} \mathrm{NADH}, 1.0 \mathrm{mmol} \cdot \mathrm{L}^{-1}$ ascorbate, 1.0 unit of ascorbate oxidase, and $100 \mu \mathrm{L}$ enzyme extract. The reaction was initiated by adding ascorbate oxidase (Erkan et al., 2008).

For dehydroascorbate reductase (DHAR, EC 1.5.5.1), the increase in absorbance at $265 \mathrm{~nm}$ was measured as a result of ASC formation (extinction coefficient of $14 \mathrm{mM} \cdot \mathrm{cm}^{-1}$ ). The reaction mixture $(3 \mathrm{~mL})$ contained $100 \mathrm{mM}$ Hepes- $\mathrm{KOH}$ ( $\mathrm{pH} 7.0), 1 \mathrm{mM}$ EDTA, $2.5 \mathrm{mM}$ reduced glutathione $(\mathrm{GSH})$, $0.2 \mathrm{mM}$ dehydroascorbate (DAsA) and $100 \mu \mathrm{L}$ enzyme extract. The reaction was initiated by adding DAsA (Dalton et al., 1986).

For GR (EC1.6.4.2), the decrease in absorbance at $340 \mathrm{~nm}$ was measured as a result of NADPH oxidation (extinction coefficient of $\left.6.22 \mathrm{mM} \cdot \mathrm{cm}^{-1}\right)$. The reaction mixture $(3 \mathrm{~mL})$ contained
100 mM Tris-HCl ( $\mathrm{pH}$ 8.0), $1 \mathrm{mM}$ EDTA, $1 \mathrm{mM}$ oxidized glutathione (GSSG), $0.2 \mathrm{mM} \mathrm{NADPH}$, and $100 \mu \mathrm{L}$ enzyme extract. The reaction was initiated by adding NADPH (Grace and Logan, 1996).

\section{RNA Isolation and Quantitative Real-Time RT-PCR}

Total RNA was extracted from leaves with a plant RNA kit (Omega Bio-Tek, Doraville, GA, USA) and then reversetranscribed using a PrimeScript ${ }^{\mathrm{TM}}$ RT reagent kit with gDNA Eraser (Takara, Shiga, Japan) according to the manufacture's instruction. Real-time PCR was carried out on a StepOne ${ }^{\mathrm{TM}}$ Plus real-time PCR system (Applied Biosystems, USA) using a SYBR Premix EX Taq kit (Taraka). The specific primers (Supplementary Table S1) used in the present study were designed using Primer Premier 6 software (Biosoft International, Palo Alto, CA, USA). The actin gene acted as the internal standard. Relative fold expression changes were calculated using the $\left(2^{-\Delta \Delta C_{t}}\right)$ method.

\section{Transmission Electron Microscope (TEM) Analyses}

Small pieces $\left(\sim 1 \mathrm{~mm}^{2}\right)$ cut from the same region of different leaves were fixed with $4 \%$ glutaradehyde in $0.2 \mathrm{mM}$ sodium phosphate buffer ( $\mathrm{pH}$ 6.8) for $6 \mathrm{~h}$ at $4^{\circ} \mathrm{C}$. After washing with 0.1 $\mathrm{M}$ sodium phosphate buffer ( $\mathrm{pH} 6.8$ ), the tissue pieces were postfixed for $2.5 \mathrm{~h}$ in $1 \%$ osmic acid in $0.2 \mathrm{mM}$ sodium phosphate buffer ( $\mathrm{pH}$ 6.8) and re-washed with $0.1 \mathrm{M}$ sodium phosphate buffer ( $\mathrm{pH}$ 6.8). Following dehydration in a graded series of 


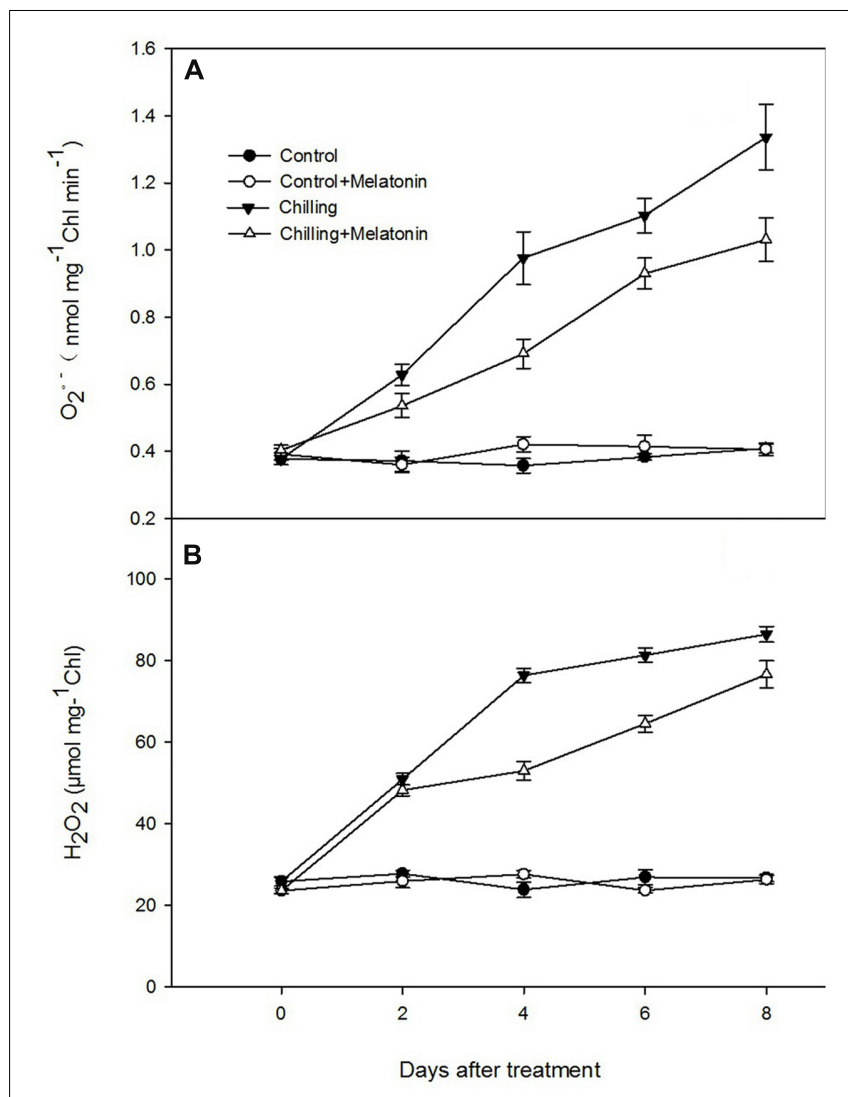

FIGURE 4 | Effects of exogenous melatonin on (A) superoxide anion $\left(\mathrm{O}_{2}-\right)$ and $(\mathbf{B})$ hydrogen peroxide $\left(\mathrm{H}_{2} \mathrm{O}_{2}\right)$ contents of chloroplasts under chilling stress. Control $\left(28 / 18^{\circ} \mathrm{C}\right)$; Control + Melatonin $\left(200 \mu \mathrm{M}\right.$ melatonin, $\left.28 / 18^{\circ} \mathrm{C}\right)$; Chilling $\left(15 / 8^{\circ} \mathrm{C}\right)$; Chilling + Melatonin $\left(200 \mu \mathrm{M}\right.$ melatonin, $\left.15 / 8^{\circ} \mathrm{C}\right)$. Data are means $\pm S D$ of three replicates.

ethanol solutions, the tissue pieces were embedded in Epon812 and sectioned using an ultramicrotome (EM UC7, Leica Microsystems GmbH, Germany). A TEM (JEM-1230, JEOL, Japan) was used to assay the ultrathin sections stained with uranyl acetate and lead citrate.

\section{Leaf Gas Exchange and Chlorophyll Fluorescence Analyses}

For leaf gas exchange and chlorophyll fluorescence analysis, plants were placed in a growth chamber at $25^{\circ} \mathrm{C}$ and held for $1 \mathrm{~h}$ at a photon flux density of $600 \mu \mathrm{mol} \cdot \mathrm{m}^{-2} \cdot \mathrm{s}^{-1}$ before measurement. Leaf gas exchange and chlorophyll fluorescence parameters were measured simultaneously using a portable photosynthesis system (LI-6400XT, LI-COR, USA) equipped with a leaf chamber fluorimeter (LI6400-40, LI-COR, USA) under both photorespiratory $\left(21 \% \mathrm{O}_{2}\right)$ and non-photorespiratory $(2 \%$ $\mathrm{O}_{2}$ ) conditions (Zhou et al., 2004). The air temperature, $\mathrm{CO}_{2}$ concentration and photosynthetic photon flux intensity (PPFD) were set at $25^{\circ} \mathrm{C}, 350 \mu \mathrm{mol} \cdot \mathrm{mol}^{-1}, 600 \mu \mathrm{mol} \cdot \mathrm{m}^{-2} \cdot \mathrm{s}^{-1}$. The A-Ci curves under PPFD 300 and $600 \mu \mathrm{mol} \cdot \mathrm{m}^{-2} \cdot \mathrm{s}^{-1}$ were measured between 0 and $1200 \mu \mathrm{mol} \cdot \mathrm{mol}^{-1} \mathrm{CO}_{2}$ at $21 \% \mathrm{O}_{2}$ and $25^{\circ} \mathrm{C}$ (Brooks and Farquhar, 1985).

\section{Estimation of the Rate of Electron Flux}

The rate of electron transport through PSII [Je(PSII)] is equal to $\alpha \times \Phi($ PSII $) \times$ PPFD where $\alpha$ is the absorbance coefficient ratio of allocation of excitation energy to PSIIwhich can be expressed as $4 \times(\mathrm{A}+\mathrm{Rd}) /[\mathrm{PFD} \times \Phi(\mathrm{PSII})]$ under non-photorespiratory conditions (Genty et al., 1989; Miyake and Yokota, 2000). The rate of carboxylation by Rubisco (Vc) was calculated according to the description of Miyake [25], and the rate of oxygenation by Rubisco (Vo) following Von Caemmerer and Farquhar (1981; Miyake and Yokota, 2000). The electron flux in the PCR cycle $[J e(P C R)]$ equals $4 \times \mathrm{Vc}$ while the electron flux in the $\mathrm{PCO}$ cycle $[\mathrm{Je}(\mathrm{PCO})]$ is equal to $4 \times \mathrm{Vo}$ (Krall and Edwards, 1992). The alternative flux (Ja) can be expressed as Je(PSII)$\boldsymbol{J e}$ (PCR- Je(PCO) (Miyake and Yokota, 2000). The $\mathrm{O}_{2}^{-}$dependent alternative electron flux $\boldsymbol{J a}\left(\mathrm{O}_{2}^{-}\right.$dependent) equals $\boldsymbol{J a}\left(21 \% \mathrm{O}_{2}\right)$ $\boldsymbol{J a}\left(2 \% \mathrm{O}_{2}\right)$ (Miyake and Yokota, 2000).

\section{Statistical Analyses}

The data are expressed as the means \pm standard deviations of three replicate samples. One way ANOVA was used to analyze all data followed by Duncan's multiple range tests. A probability of $P<0.05$ was considered statistically significant.

\section{RESULTS}

\section{Ultrastructural Changes in Chloroplasts}

To examine whether melatonin could alleviate damage to chloroplasts induced by chilling, we investigated chloroplast ultrastructure. Under standard temperature conditions, chloroplasts were attached to the cell wall and exhibited typical ellipsoidal shapes. Regularly arranged grana lamellae were interconnected by well-developed stromal lamellae (Figures 2A-F). Under chilling stress, the chloroplasts became swollen and contained more starch grains and the lamella system was also swollen and indistinct (Figures 2G-I). Application of exogenous melatonin significantly reduced chloroplast damage indicated by a more normal chloroplast ultrastructure (Figures 2J-L).

\section{MDA Contents and ROS Levels}

Further, we monitored chloroplast MDA content. Our data confirm that chilling induced dramatic accumulations of MDA in chloroplasts (Figure 3). Between day 2 and day 6, the MDA content rose sharply, followed by a further slight increase over the next 2 days. However, exogenous melatonin application not only delayed the rise by 2 days but also weakened it.

The rate of generation of $\mathrm{O}_{2}^{-}$increased sharply during chilling while melatonin significantly reduced this increase especially at days 4 and 8 (Figure 4A). During the first 4 days, $\mathrm{H}_{2} \mathrm{O}_{2}$ levels rose dramatically and then increased slowly over the following days (Figure 4B). After 2 days, melatonin markedly suppressed the strong production of $\mathrm{H}_{2} \mathrm{O}_{2}$ and the inhibition gradually subsided as time passed. Those results were corroborated by observation of $\mathrm{H}_{2} \mathrm{O}_{2}$ production, seen as epifluorescence from chloroplast infiltrated with DCFH-DA. 


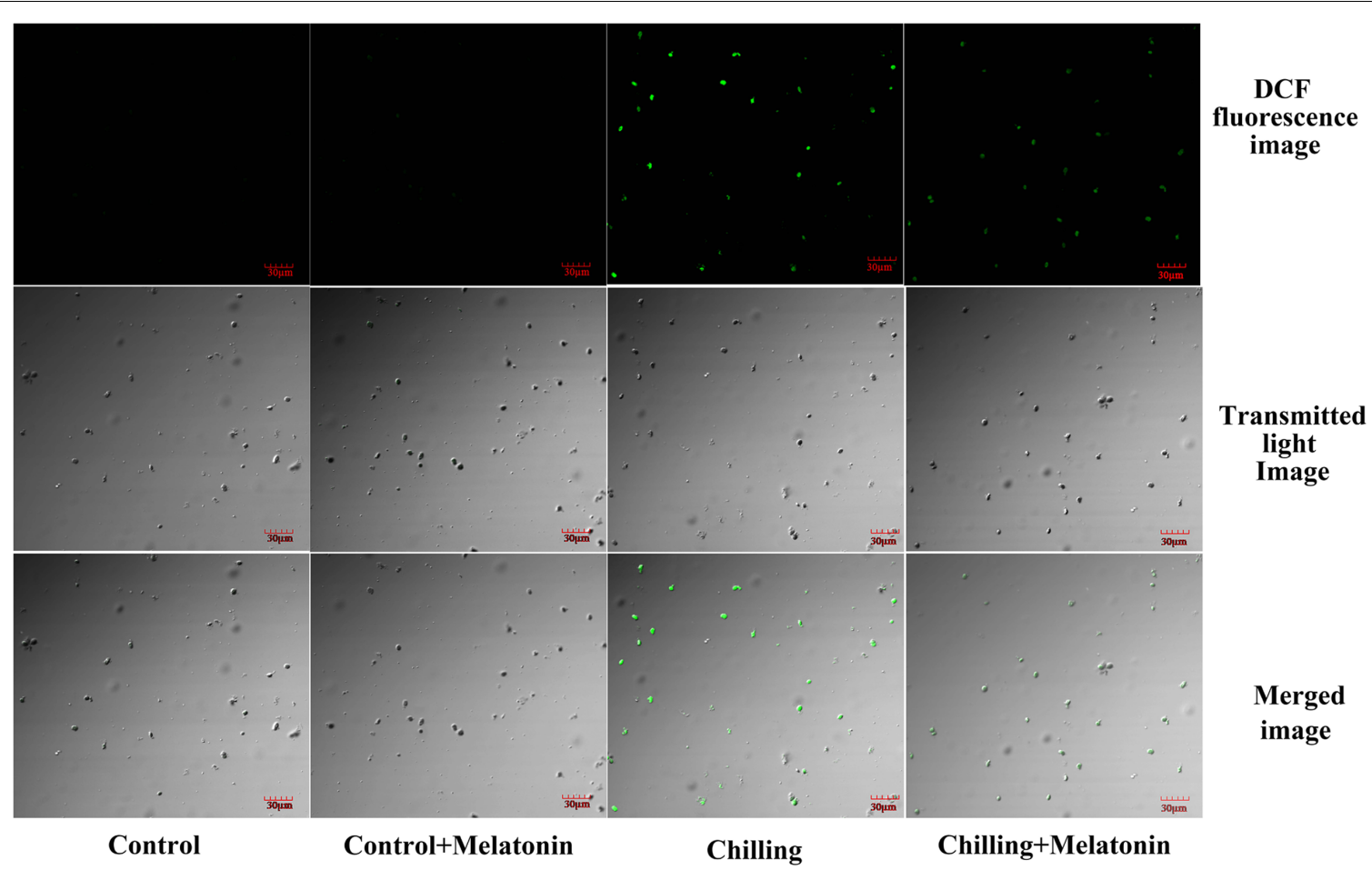

FIGURE 5 | Confocal laser scanning micrographs of DCFH-infiltrated chloroplast. The second, fully expanded leaves were measured after 4 days of chilling. Control $\left(28 / 18^{\circ} \mathrm{C}\right)$; Control + Melatonin $\left(200 \mu \mathrm{M}\right.$ melatonin, $\left.28 / 18^{\circ} \mathrm{C}\right)$; Chilling $\left(15 / 8^{\circ} \mathrm{C}\right)$; Chilling + Melatonin $\left(200 \mu \mathrm{M}\right.$ melatonin, $\left.15 / 8^{\circ} \mathrm{C}\right)$. DCF fluorescence, indicative of $\mathrm{H}_{2} \mathrm{O}_{2}$; Transmitted light image, indicative of the number of chloroplasts; Merged image, combination of DCF fluorescence image and Transmitted light image.

Chilling treatment present the strongest fluorescence while the fluorescence intensity of Chilling + Melatonin treatment was weaker than that of chilling treatment (Figure 5). Under nonstress conditions, And, $\mathrm{O}_{2}^{-}$and $\mathrm{H}_{2} \mathrm{O}_{2}$ levels in chloroplasts were little affected by melatonin.

\section{AsA-GSH Cycle}

The interconversions between oxidized and reduced ascorbic and glutathione in chloroplasts were also investigated. Under chilling stress, the contents of AsA, and total AsA both increased dramatically over the first 2 days and then continued to climb more slowly over the following 6 days. This pattern was similar but slightly stronger in the melatonin-treated plants (Figures 6A,C). Chilling stress also led to a dramatic increase in DHA content but melatonin did not lead to any additional change except at day 8 (Figure 6B). Melatonin also led no change on GSSG content (Figure 6F). Levels of AsA/DHA decreased markedly, induced by chilling but were clearly mitigated by melatonin (Figure 6D). Meanwhile, levels of GSH/GSSG followed a similar pattern (Figure $\mathbf{6 H}$ ). Chilling stress resulted in a sharp increase in the contents of GSH and total GSH over the first 6 days with the increase being reinforced by melatonin treatment - especially on days 4 and 6 (Figures 6E,G).

Chilling stress dramatically increased the activities of the chloroplast antioxidant enzymes. Thus, under chilling, SOD activity increased dramatically over the first 2 days, before peaking on day 2 and then decreasing over the following days (Supplementary Figure S1). However, melatonin significantly delayed this later decrease. The activities of APX and DHAR climbed rapidly during chilling, and this trend was strengthened by melatonin (Figures 7A,C). The activities of MDHAR and GR increased with chilling until day 4 and then fluctuated over the following few days (Figures 7B,D). Melatonin clearly increased the activities of MDHAR and GR.

Expression levels of genes involved in the biosynthesis of these enzymes of ASA-GSH cycle were evaluated at the transcriptional level. The expression levels of CsCu-ZnSOD, CsFeSOD, CsAPX, $C s M D H A R, C s D H A R$ and $C s G R$ were significantly upregulated by chilling from day 2 (Figure 8). Compared with that of chilling treatment, the expression of $\mathrm{CsCu}-\mathrm{ZnSOD}$ was further upregulated by melatonin during the whole period while CsFeSOD was only upregulated on day 4. Moreover, melatonin significantly upregulated the expression level of CsAPX (on days 2 and 8), CsDHAR (on days 4 day 8) and CsGR (on days 2 and 6) compared with chilling treatment. And, the expression level of CsMDHAR was only upregulated by melatonin on day 6 .

\section{Electric Flux in Photosystem}

With chilling, $\boldsymbol{J} \boldsymbol{e}(\mathrm{PSII})$ and $\boldsymbol{J} \boldsymbol{e}(\mathrm{PCR})$ slumped by 43 and $71 \%$ while $\boldsymbol{J} \boldsymbol{e}(\mathrm{PCO})$ and $\boldsymbol{J} \boldsymbol{a}\left(\mathrm{O}_{2}\right.$-independent) increased by 11 and $74 \%$, compared with the controls (Table 1). Moreover, Ja and $\boldsymbol{J a}\left(\mathrm{O}_{2}\right.$-dependent $)$ were between 3 - and 8-times higher than in 


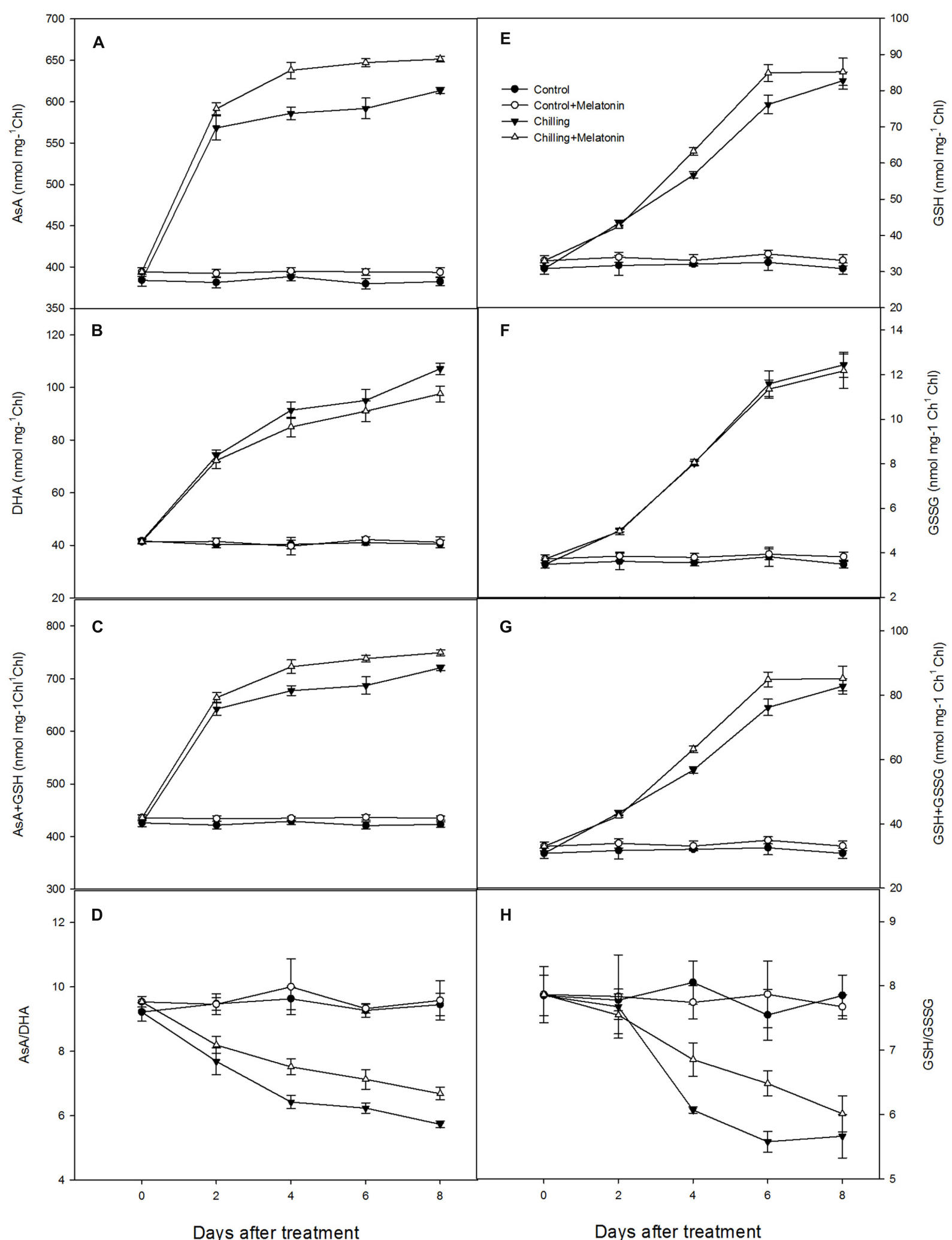

FIGURE 6 | Effects of exogenous melatonin on antioxidant content of chloroplasts under chilling stress: (A) ascorbic acid (AsA), (B) dehydroascorbate (DHA), (C) AsA + DHA, (D) AsA/DHA, (E) glutathione (GSH), (F) oxidized glutathione (GSSG), (G) GSH + GSSG, (H) GSH/GSSG. Control (28/18 C);

Control + Melatonin $\left(200 \mu \mathrm{M}\right.$ melatonin, $\left.28 / 18^{\circ} \mathrm{C}\right)$; Chilling $\left(15 / 8^{\circ} \mathrm{C}\right)$; Chilling + Melatonin $\left(200 \mu \mathrm{M}\right.$ melatonin, $\left.15 / 8^{\circ} \mathrm{C}\right)$. Data are means $\pm \mathrm{SD}$ of three replicates. 


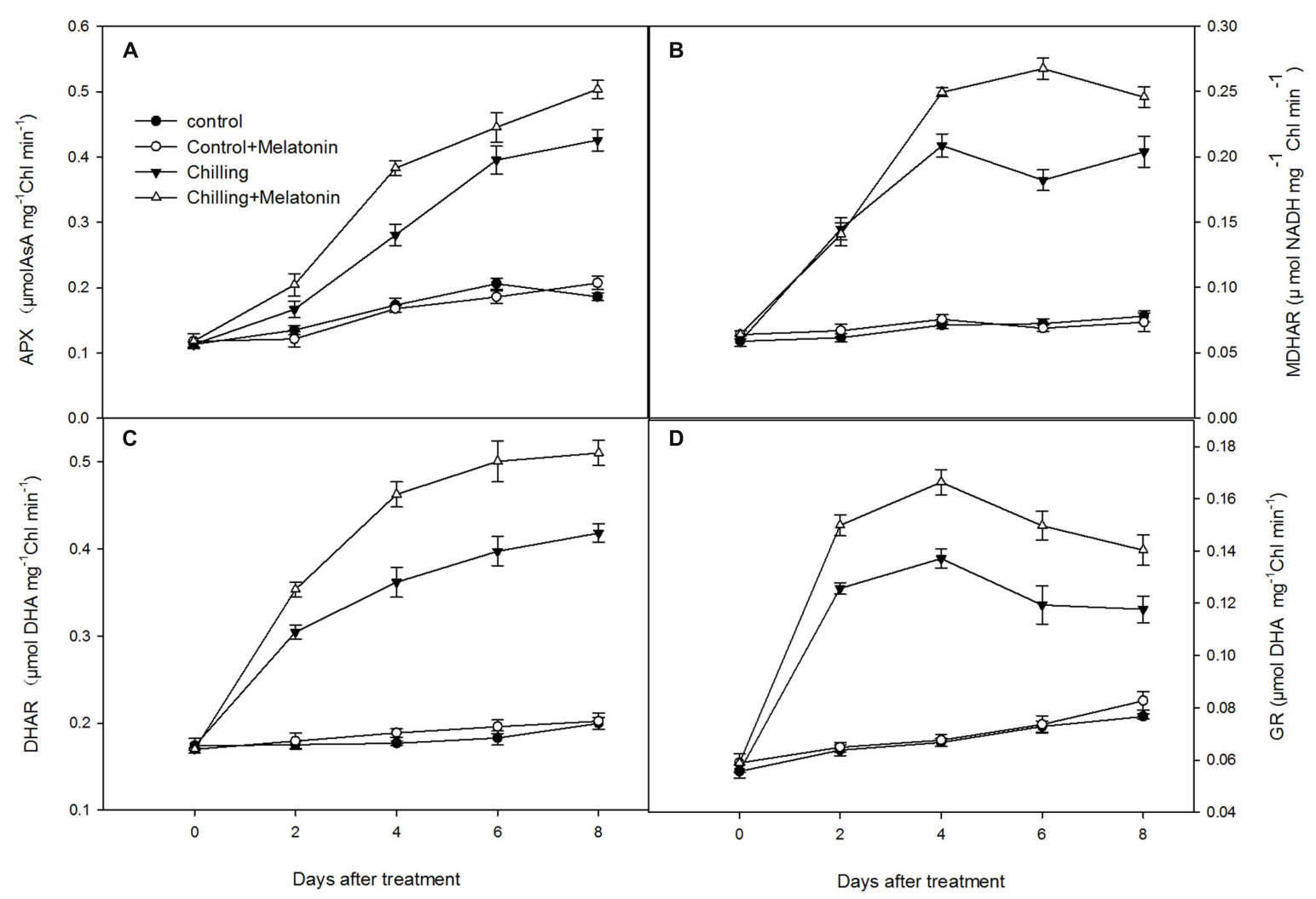

FIGURE 7 | Effects of exogenous melatonin on activities of key enzymes in ascorbic acid - glutathione (AsA-GSH) cycle in chloroplasts under chilling stress. (A) ascorbate peroxidase (APX), (B) monodehydroascorbate reductase (MDHAR), (C) dehydroascobate reductase (DHAR), (D) glutathione reductase (GR). Control $\left(28 / 18^{\circ} \mathrm{C}\right)$; Control + Melatonin (200 $\mu \mathrm{M}$ melatonin, $\left.28 / 18^{\circ} \mathrm{C}\right)$; Chilling $\left(15 / 8^{\circ} \mathrm{C}\right)$; Chilling + Melatonin $\left(200 \mu \mathrm{M}\right.$ melatonin, $\left.15 / 8^{\circ} \mathrm{C}\right)$. Data are means $\pm \mathrm{SD}$ of three replicates.

the controls. However, melatonin slightly decreased Je(PSII) and $\boldsymbol{J} \boldsymbol{e}(\mathrm{PCR})$ and increased $\boldsymbol{J a}$ and $\boldsymbol{J a}\left(\mathrm{O}_{2}\right.$-dependent $)$ and increased the growth of $\boldsymbol{J a}(\mathrm{PCO})$ and $\boldsymbol{J a}\left(\mathrm{O}_{2}\right.$-independent). Under unchilled conditions, melatonin had no significant effect on electron flows, though $\mathbf{J e}(\mathrm{PCO})$ did increase by about $20 \%$.

\section{DISCUSSION}

\section{Melatonin Alleviates Chilling Damage With Cucumber Chloroplasts}

Cucumber is an important salad crop but it is very sensitive to chilling (Xu et al., 2008). Under chilling stress, chloroplasts, the primary site of the photosynthetic reactions, commonly present signs of membrane damage. This is because chloroplasts are a major source of ROS which cause membrane lipid peroxidation (Asada, 2006; Gill and Tuteja, 2010). The degree of membrane damage in chloroplasts can be seen in their ultrastructure (Yuan et al., 2012; Shu et al., 2013; Shao et al., 2014). Our results show that under chilling, the chloroplasts swell and alter their typical ellipsoidal shape (Figures 2G-I). Melatonin significantly alleviates these indications of chilling damage with their shape and structure appearing normal.

\section{Melatonin Reduces the ROS Levels and MDA Contents in Cucumber Chloroplasts}

Accumulation of ROS such as $\mathrm{O}_{2}^{-}$and $\mathrm{H}_{2} \mathrm{O}_{2}$ occurred under chilling and was associated with signs of chloroplast damage. Although low levels of ROS are indispensable, excessive accumulations had been shown to be associated with damage from lipid peroxidation, and oxidation of protein and DNA (Gill and Tuteja, 2010; Heidarvand and Amiri, 2010; Xia et al., 2014). Lipid peroxidation from excessive ROS leads to structural abnormalities and cell dysfunction of (Gill and Tuteja, 2010). Malonaldehyde is usually considered an indicator of membrane structural integrity (Xi et al., 2013). In the present study, chloroplast MDA content increased dramatically (Figure 3) under chilling as a result of production of $\mathrm{O}_{2}^{-}$and $\mathrm{H}_{2} \mathrm{O}_{2}$ (Figures 4 and 5). However, with melatonin these negative indications were significantly reduced. This is consistent with the finding reported by Wang et al. (2016) in cucumber under salinity-induced stress. Thus it is clear that melatonin helps to reduce membrane damage caused by over-accumulation of ROS. Other studies have shown that exogenous melatonin can decrease ROS in plants exposed to salinity stress (Li et al., 2012), drought stress (Zhang et al., 2013) and during senescence (Wang et al., 


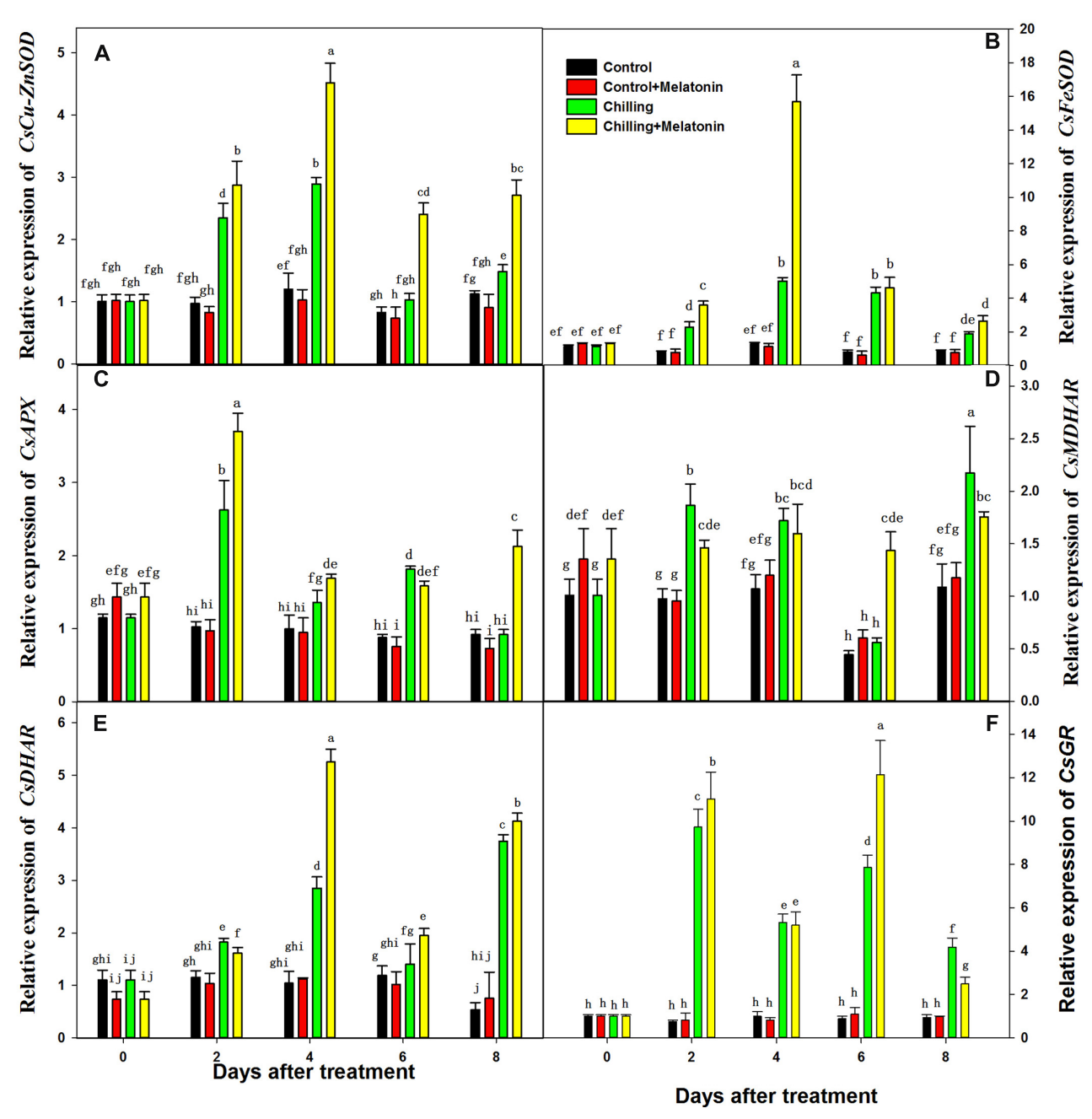

FIGURE 8 | Effects of exogenous melatonin on transcript levels of key genes involved in biosynthesis of enzymes of ASA-GSH cycle under chilling stress. (A) CsCu-ZnSOD, (B) CsFeSOD, (C) CsAPX, (D) CsMDHAR, (E) CsDHAR, (F) CsGR. Control (28/18 $\left.{ }^{\circ} \mathrm{C}\right)$; Control + Melatonin (200 $\mu \mathrm{M}$ melatonin, 28/18 $\left.{ }^{\circ} \mathrm{C}\right)$; Chilling $\left(15 / 8^{\circ} \mathrm{C}\right)$; Chilling + Melatonin $\left(200 \mu \mathrm{M}\right.$ melatonin, $\left.15 / 8^{\circ} \mathrm{C}\right)$. Data are means $\pm \mathrm{SD}$ of three replicates.

2012). Consistent with these studies, our results confirm that melatonin can protect chloroplasts from ROS damage under chilling stress.

\section{Melatonin Regulates ROS Metabolism Through Both Their Generation and Their Elimination}

The level of ROS in a chloroplast depends on the balance between the rate at which they are generated and that at which they are eliminated. Here, we explored the role of melatonin in regulating ROS metabolism - both their generation and their elimination in chloroplasts of chilling-stressed cucumbers (Figure 1).

An important and efficient ROS-scavenging pathway in chloroplasts is the AsA-GSH cycle (Palma et al., 2006). After $\mathrm{O}_{2}^{-}$ has been reduced by SOD to $\mathrm{H}_{2} \mathrm{O}_{2}$, the excess levels of $\mathrm{H}_{2} \mathrm{O}_{2}$ are scavenged by transforming it to $\mathrm{H}_{2} \mathrm{O}$ under catalysis by APX using AsA as the electron donor. Meanwhile, AsA is oxidized to
MDHA, which is then reduced directly to AsA by MDHAR or first degraded to DHA and then be reduced to AsA by DHAR using GSH as the reducing substrate. The oxidized substrate of GSH, GSSG, can be reduced to GSH by GR (Davey et al., 2000). Chilling stress leads to decreases in AsA/DHA and to increases in AsA, DHA and total AsA (Figure 6). The decrease in AsA/DHA shows a higher percentage of AsA is transformed to the oxidized state in response to increased oxidative stress. Moreover, melatonin increased the AsA content, but had no significant influence on the DHA content (Figures 6A,B). This indicates that melatonin may elevate the AsA sink by increasing AsA content and is also helpful in maintaining a high level of AsA/DHA. Similar founding appeared in GSH and GSSG (Figures 6E,F). Maintaining the efficient recycling of AsA via APX, MDHAR and DHAR is crucial to maintaining AsA in a high redox state so that it scavenges $\mathrm{H}_{2} \mathrm{O}_{2}$ efficiently (Conklin and Barth, 2004). Ascorbate is an important antioxidant in the AsA-GSH cycle and usually works in combination with GSH (Nagalakshmi and Prasad, 
TABLE 1 | Effects of exogenous melatonin on photosynthetic electron partitions after four days chilling stress.

\begin{tabular}{|c|c|c|c|c|c|c|}
\hline Treatments & $\begin{array}{c}\mathrm{Je}(\mathrm{PSII}) \\
\mu \mathrm{molm}^{-2} \mathrm{~s}^{-1}\end{array}$ & $\begin{array}{c}\mathrm{Je}(\mathrm{PCR}) \\
\mu \mathrm{molm}^{-2} \mathrm{~s}^{-1}\end{array}$ & $\begin{array}{c}\mathrm{Je}(\mathrm{PCO}) \\
\mu \mathrm{molm}^{-2} \mathrm{~s}^{-1}\end{array}$ & $\begin{array}{c}\mathrm{Ja21} \% \\
\mu \mathrm{molm}^{-2} \mathrm{~s}^{-1}\end{array}$ & $\begin{array}{c}\mathrm{Ja}\left(\mathrm{O}_{2} \text {-independent }\right) \\
\mu \mathrm{molm}^{-2} \mathrm{~s}^{-1}\end{array}$ & $\begin{array}{c}\mathrm{Ja}\left(\mathrm{O}_{2} \text {-dependent }\right) \\
\mu \mathrm{molm}^{-2} \mathrm{~s}^{-1}\end{array}$ \\
\hline Control & $75.57 \pm 0.86 a$ & $61.01 \pm 0.77 a$ & $11.60 \pm 0.79 c$ & $2.96 \pm 0.41 c$ & $1.97 \pm 0.20 c$ & $0.99 \pm 0.22 c$ \\
\hline Melatonin & $77.27 \pm 2.86 a$ & $60.02 \pm 1.88 \mathrm{a}$ & $14.10 \pm 0.90 b$ & $3.16 \pm 0.16 c$ & $2.20 \pm 0.16 c$ & $0.96 \pm 0.12 c$ \\
\hline Chilling & $43.35 \pm 1.57 c$ & $17.8 \pm 0.41 \mathrm{c}$ & $12.85 \pm 0.52 b c$ & $12.82 \pm 0.90 a$ & $3.42 \pm 0.28 b$ & $9.40 \pm 1.12 \mathrm{a}$ \\
\hline Chilling + Melatonin & $52.97 \pm 1.41 b$ & $24.51 \pm 0.12 b$ & $18.32 \pm 0.61 a$ & $10.14 \pm 1.10 b$ & $4.41 \pm 0.44 a$ & $5.73 \pm 0.66 b$ \\
\hline
\end{tabular}

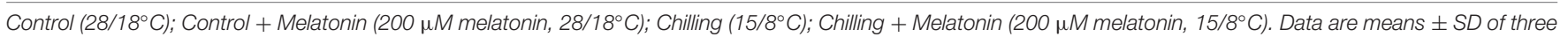
replicates. Different letters indicate significant $(P<0.05)$ differences based on Duncan's multiple range text.

2001). Under chilling stress, the total AsA content rose to a high level at day 2 (Figure 6C) while the activity of APX, DHAR and MDHAR increased relatively slowly in the early period (Figure 7). This indicates that AsA biosynthesis plays a dominant role in maintaining a high ratio of AsA/GSH in the early period, while the efficient recycling of AsA in the later period was due mainly to the high activity of APX, DHAR and MDHAR. The key enzyme catalyzing the reduction from $\mathrm{H}_{2} \mathrm{O}_{2}$ to $\mathrm{H}_{2} \mathrm{O}$ is $\mathrm{APX}$, and this uses AsA as electron donor while the recycling of AsA is dependent on MDHAR and DHAR (Wang et al., 2013). Melatonin has been shown to stimulate the activity of APX, DHAR and MDHAR(Wang et al., 2012). Ascorbate peroxidase is found in apple leaves under oxidative stress (Wang et al., 2012). This finding is in accordance with our results (Figures 6A-C). The recycling of AsA must also be coupled with the recycling of GSH catalyzed by GR. A high GSH/GSSG ratio helps the recycling of AsA by maintaining an appropriate redox environment and reducing oxidative stress (Wang et al., 2013). Studies in animals show that melatonin can stimulate $\gamma$-gulamylcysteine synthetase to preserve GSH levels in cells exposed to ROS (Urata et al., 1999). Melatonin can also accelerate GSH in apple leaves (Wang et al., 2012). Our findings are similar (Figure 6D). SOD can accelerate the reduction from $\mathrm{O}_{2}^{-}$to $\mathrm{H}_{2} \mathrm{O}_{2}$ which is an earlier reaction of AsA-GSH. Our results also show that melatonin helps to enhance SOD activity during chilling (Supplementary Figure S1). This finding is consistent with an earlier study in apple leaves under salt stress (Li et al., 2012). Our results demonstrate that melatonin activated the AsA-GSH cycle by enhancing the activity of SOD, APX, MDHAR, DHAR and GR, and by increasing the contents of AsA and GSH thus maintaining a high level of AsA/DHA and GSH/GSSG under chilling stress. Apart of that, we also found that the enhancement in activities of enzymes of AsA-GSH cycle was related the upregulation of genes involved in the biosynthesis of these enzymes of ASA-GSH cycle induced by melatonin. The study confirms that the AsAGSH cycle plays an important role in mitigating the function of exogenous melatonin under chilling conditions. The AsAGSH cycle, an important antioxidant system in higher plants, has been reported in chloroplasts, mitochondria, peroxisomes and cytoplasm of higher plants (Palma et al., 2006; Zhang et al., 2015b). Just how melatonin stimulates the AsA-GSH cycle is not clear, however, suggesting further investigation in this area would be worthwhile.

The generation of ROS in chloroplasts is closely correlated with the electron flux in the photosystem (Jiang et al., 2013). Under normal conditions, the photon energy absorbed by chlorophyll is mainly converted to chemical energy and stored in the form of NADPH and ATP through photosynthetic linear flow of electrons. In C3 plants, NADPH and ATP are the sources of energy in both the photosynthetic carbon-reduction (PCR) cycle and the photorespiration carbon-oxidation (PCO) cycle. Under stress, however, the consumption of NADPH and ATP falls below the rate of photosynthetic linear flow of electrons, on account of the reduced activity of the PCR and PCO cycles. After that, the photosynthetic linear flux of electrons $[\boldsymbol{J e}(\mathrm{PCR})$ and $\boldsymbol{J e}(\mathrm{PCO})]$ is full and part of the excessive electron will flow into alternative electron flux depends on the partial pressure of $\mathrm{O}_{2}\left[\mathbf{J a}\left(\mathrm{O}_{2}\right.\right.$ depend)], which will reduce $\mathrm{O}_{2}$ and lead to overexpression of ROS (Miyake and Yokota, 2000, 2001; Peeva et al., 2012). Under chilling stress, the $\mathrm{O}_{2}$-dependent alternative electron flux increases indicating a high proportion of electrons transported to $\mathrm{O}_{2}$ producing ROS (Zhou et al., 2004; Liu et al., 2012; Jiang et al., 2013). Consistent with our study, $\mathbf{J a}\left(\mathrm{O}_{2}\right.$-dependent) increased dramatically while $\boldsymbol{J} \boldsymbol{e}$ (PSII) and $\boldsymbol{J e}$ (PCR) decreased sharply under chilling (Table 1). These behaviors imply that a considerable excess of energy was trapped which was then consumed through the alternative electron flux depending on the partial pressure of $\mathrm{O}_{2}$, this led to overproduction of ROS. In our experiments, melatonin not only maintained high levels of $\boldsymbol{J e}(\mathrm{PSII}), \boldsymbol{J e}$ (PCR) and $\boldsymbol{J e}(\mathrm{PCO})$ but also significantly suppressed the increase of $\boldsymbol{J a}\left(\mathrm{O}_{2}\right.$-dependent) (Table $\left.\mathbf{1}\right)$. This indicated melatonin could play an important role in maintaining the capacity of PCR and PCO cycles to consume surplus photosynthetic electrons, thus decreasing the alternative electron flux depending on the partial pressure of $\mathrm{O}_{2}$. Similar results have been reported previously. Thus, Wei [56] found that Pet F, an electron transporter gene, and $r b c S, G A P C 1, G A P C P-2$, genes in the Calvin cycle were upregulated by melatonin in salt-stressed soybean plants. Melatonin also helped maintain the photosynthesis rate of apple leaves under salt stress and senescence (Li et al., 2012; Wang et al., 2012). The sharp increase in $\boldsymbol{J e}(\mathrm{PCO})$ suggests that photorespiration may play a key role in melatonin regulation. Our results indicate that melatonin helps maintain the PCR and PCO cycles and lessen the alternative electron flows depending on the $\mathrm{O}_{2}$ partial pressure which is closely related the production of ROS.

\section{CONCLUSION}

We found that chilling stress led to serious chloroplast damage due to over-accumulation of ROS. Exogenous melatonin 
increased the chilling tolerance of chloroplast in cucumber seedlings by enhancing the AsA-GSH cycle to increase the ROS scavenging capacity and by adjusting photosynthetic electron flux so as to suppress the production of ROS.

\section{AUTHOR CONTRIBUTIONS}

ZZ, HZ, and YW designed the experiments, HZ, LY, XZ, JY, and JW carried out the experiments, HZ, YW, and KC contributed to the writing of the manuscript.

\section{FUNDING}

This research was supported by Basic Vegetable Industry System (No. Z225020802), Key Technology Integration and Demonstration of Horticultural Crops Growing on

\section{REFERENCES}

Afreen, F., Zobayed, S., and Kozai, T. (2006). Melatonin in Glycyrrhiza uralensis: response of plant roots to spectral quality of light and UV-B radiation. J. Pineal Res. 41, 108-115. doi: 10.1111/j.1600-079X.2006.00337.x

Allen, D. J., and Ort, D. R. (2001). Impacts of chilling temperatures on photosynthesis in warm-climate plants. Trends Plant Sci. 6, 36-42. doi: 10.1016/ S1360-1385(00)01808-2

Arnao, M. B., and Hernández-Ruiz, J. (2014). Melatonin: plant growth regulator and/or biostimulator during stress? Trends Plant Sci. 19, 789-797. doi: 10.1016/ j.tplants.2014.07.006

Arnao, M. B., and Hernández-Ruiz, J. (2013). Growth conditions determine different melatonin levels in Lupinus albus L. J. Pineal Res. 55, 149-155. doi: 10.1111/jpi.12055

Arnao, M. B., and Hernández-Ruiz, J. (2015). Functions of melatonin in plants: a review. J. Pineal Res. 59, 133-150. doi: 10.1111/jpi.12253

Asada, K. (2006). Production and scavenging of reactive oxygen species in chloroplasts and their functions. Plant Physiol. 141, 391-396. doi: 10.1104/pp. 106.082040

Bajwa, V. S., Shukla, M. R., Sherif, S. M., Murch, S. J., and Saxena, P. K. (2014). Role of melatonin in alleviating cold stress in Arabidopsis thaliana. J. Pineal Res. 56, 238-245. doi: 10.1111/jpi.12115

Bao, G., Zhuo, C., Qian, C., Xiao, T., Guo, Z., and Lu, S. (2015). Co-expression of NCED and ALO improves vitamin C level and tolerance to drought and chilling in transgenic tobacco and stylo plants. Plant Biotechnol. J. 14, 206-214. doi: $10.1111 /$ pbi.12374

Brooks, A., and Farquhar, G. (1985). Effect of temperature on the CO2/O2 specificity of ribulose-1, 5-bisphosphate carboxylase/oxygenase and the rate of respiration in the light. Planta 165, 397-406. doi: 10.1007/BF00 392238

Burkhardt, S., Tan, D. X., Manchester, L. C., Hardeland, R., and Reiter, R. J. (2001). Detection and quantification of the antioxidant melatonin in Montmorency and Balaton tart cherries (Prunus cerasus). J. Agric. Food Chem. 49, 4898-4902.

Chao, L., Liang, M., Cong, C., Wei, Z., Zhou, S., and Ma, F. (2016). Exogenous melatonin improved potassium content in Malus under different stress conditions. J. Pineal Res. 61, 218-229. doi: 10.1111/jpi.12342

Chen, G., Huo, Y., Tan, D.-X., Liang, Z., Zhang, W., and Zhang, Y. (2003). Melatonin in Chinese medicinal herbs. Life Sci. 73, 19-26. doi: 10.1016/S00243205(03)00252-2

Conklin, P., and Barth, C. (2004). Ascorbic acid, a familiar small molecule intertwined in the response of plants to ozone, pathogens, and the onset of senescence. Plant Cell Environ. 27, 959-970. doi: 10.1111/j.1365-3040.2004. 01203.x

Dalton, D. A., Russell, S. A., Hanus, F., Pascoe, G. A., and Evans, H. J. (1986). Enzymatic reactions of ascorbate and glutathione that prevent peroxide damage
Non-cultivated Land in Northwest (NO. K312021301), 13 Doctoral Scientific Fund Project (Z223021311), Greenhouse Engineering and Environmental Regulation (NO. K332021203), and Shaanxi Province Agricultural Science and Technology Innovation and Research (2016NY165).

\section{SUPPLEMENTARY MATERIAL}

The Supplementary Material for this article can be found online at: http://journal.frontiersin.org/article/10.3389/fpls.2016.01814/ full\#supplementary-material

FIGURE S1 | Effects of exogenous melatonin on superoxide dismutase (SOD) activity in chloroplast under chilling stress. Control $\left(28 / 18^{\circ} \mathrm{C}\right)$; Control + Melatonin $\left(200 \mu \mathrm{M}\right.$ melatonin, $\left.28 / 18^{\circ} \mathrm{C}\right)$; Chilling $\left(15 / 8^{\circ} \mathrm{C}\right)$; Chilling + Melatonin $\left(200 \mu \mathrm{M}\right.$ melatonin, $\left.15 / 8^{\circ} \mathrm{C}\right)$. Data are means $\pm \mathrm{SD}$ of three replicates.

in soybean root nodules. Proc. Natl. Acad. Sci. U.S.A. 83, 3811-3815. doi: 10. 1073/pnas.83.11.3811

Davey, M. W., Montagu, M. V., Inzé, D., Sanmartin, M., Kanellis, A., Smirnoff, N., et al. (2000). Plant L-ascorbic acid: chemistry, function, metabolism, bioavailability and effects of processing. J. Sci. Food Agric. 80, 825-860. doi: 10.1002/(SICI) 1097-0010(20000515)80:7<825::AID-JSFA598>3. $0 . \mathrm{CO} ; 2-6$

Dubbels, R., Reiter, R., Klenke, E., Goebel, A., Schnakenberg, E., Ehlers, C., et al. (1995). Melatonin in edible plants identified by radioimmunoassay and by high performance liquid chromatography-mass spectrometry. J. Pineal Res. 18, 28-31. doi: 10.1111/j.1600-079X.1995.tb0 0136. $\mathrm{x}$

Erkan, M., Wang, S. Y., and Wang, C. Y. (2008). Effect of UV treatment on antioxidant capacity, antioxidant enzyme activity and decay in strawberry fruit. Postharvest Biol. Technol. 48, 163-171. doi: 10.1016/j.postharvbio.2007. 09.028

Genty, B., Briantais, J.-M., and Baker, N. R. (1989). The relationship between the quantum yield of photosynthetic electron transport and quenching of chlorophyll fluorescence. Biochim. Biophys. Acta 990, 87-92. doi: 10.1016/ S0304-4165(89)80016-9

Gill, S. S., and Tuteja, N. (2010). Reactive oxygen species and antioxidant machinery in abiotic stress tolerance in crop plants. Plant Physiol. Biochem. 48, 909-930. doi: 10.1016/j.plaphy.2010.08.016

Grace, S. C., and Logan, B. A. (1996). Acclimation of foliar antioxidant systems to growth irradiance in three broad-leaved evergreen species. Plant Physiol. 112, 1631-1640. doi: 10.1104/pp.112.4.1631

Han, Y., Wang, S., Zhao, N., Deng, S., Zhao, C., Li, N., et al. (2016). Exogenous abscisic acid alleviates cadmium toxicity by restricting $\mathrm{Cd} 2+$ influx in Populus euphratica Cells. J. Plant Growth Regul. 35, 827-837. doi: 10.1007/s00344-0169585-2

Hattori, A., Migitaka, H., Iigo, M., Itoh, M., Yamamoto, K., Ohtani-Kaneko, R., et al. (1995). Identification of melatonin in plants and its effects on plasma melatonin levels and binding to melatonin receptors in vertebrates. Biochem. Mol. Biol. Int. 35, 627-634.

Heath, R. L., and Packer, L. (1968). Photoperoxidation in isolated chloroplasts: I. Kinetics and stoichiometry of fatty acid peroxidation. Arch. Biochem. Biophys. 125, 189-198. doi: 10.1016/0003-9861(68)90654-1

Heidarvand, L., and Amiri, R. M. (2010). What happens in plant molecular responses to cold stress? Acta Physiol. Plant. 32, 419-431. doi: 10.1007/s11738009-0451-8

Hernández-Ruiz, J., Cano, A., and Arnao, M. B. (2004). Melatonin: a growthstimulating compound present in lupin tissues. Planta 220, 140-144. doi: 10. 1007/s00425-004-1317-3

Jiang, Y. P., Huang, L. F., Cheng, F., Zhou, Y. H., Xia, X. J., Mao, W. H., et al. (2013). Brassinosteroids accelerate recovery of photosynthetic apparatus from 
cold stress by balancing the electron partitioning, carboxylation and redox homeostasis in cucumber. Physiol. Plant. 148, 133-145. doi: 10.1111/j.13993054.2012.01696.x

Ke, D., Sun, G., and Wang, Z. (2007). Effects of superoxide radicals on ACC synthase activity in chilling-stressed etiolated mungbean seedlings. Plant Growth Regul. 51, 83-91. doi: 10.1007/s10725-006-9150-2

Krall, J. P., and Edwards, G. E. (1992). Relationship between photosystem II activity and CO2 fixation in leaves. Physiol. Plant. 86, 180-187. doi: 10.1111/j.13993054.1992.tb01328.x

Li, C., Wang, P., Wei, Z., Liang, D., Liu, C., Yin, L., et al. (2012). The mitigation effects of exogenous melatonin on salinity-induced stress in Malus hupehensis. J. Pineal Res. 53, 298-306. doi: 10.1111/j.1600-079X.2012.00999.x

Li, H., He, J., Yang, X., Li, X., Luo, D., Wei, C., et al. (2015). Glutathione-dependent induction of local and systemic defense against oxidative stress by exogenous melatonin in cucumber (Cucumis sativus L.). J. Pineal Res. 60, 206-216. doi: 10.1111/jpi.12304

Liu, Y., Qi, M., and Li, T. (2012). Photosynthesis, photoinhibition, and antioxidant system in tomato leaves stressed by low night temperature and their subsequent recovery. Plant Sci. 196, 8-17. doi: 10.1016/j.plantsci.2012.07.005

Logan, B. A., Grace, S. C., Adams Iii, W. W., and Demmig-Adams, B. (1998). Seasonal differences in xanthophyll cycle characteristics and antioxidants in Mahonia repens growing in different light environments. Oecologia 116, 9-17. doi: $10.1007 /$ s004420050558

Manchester, L. C., Coto-Montes, A., Boga, J. A., Andersen, L. P. H., Zhou, Z., Galano, A., et al. (2015). Melatonin: an ancient molecule that makes oxygen metabolically tolerable. J. Pineal Res. 59, 403-419. doi: 10.1111/jpi.12267

Manchester, L. C., Tan, D.-X., Reiter, R. J., Park, W., Monis, K., and Qi, W. (2000). High levels of melatonin in the seeds of edible plants: possible function in germ tissue protection. Life Sci. 67, 3023-3029. doi: 10.1016/S0024-3205(00) 00896-1

Miyake, C., and Yokota, A. (2000). Determination of the rate of photoreduction of $\mathrm{O} 2$ in the water-water cycle in watermelon leaves and enhancement of the rate by limitation of photosynthesis. Plant Cell Physiol. 41, 335-343. doi: 10.1093/ pcp/41.3.335

Miyake, C., and Yokota, A. (2001). Cyclic flow of electrons within PSII in thylakoid membranes. Plant Cell Physiol. 42, 508-515. doi: 10.1093/pcp/pce063

Murch, S. J., Hall, B. A., Le, C. H., and Saxena, P. K. (2010). Changes in the levels of indoleamine phytochemicals during véraison and ripening of wine grapes. J. Pineal Res. 49, 95-100. doi: 10.1111/j.1600-079X.2010.00774.x

Nagalakshmi, N., and Prasad, M. N. V. (2001). Responses of glutathione cycle enzymes and glutathione metabolism to copper stress in Scenedesmus bijugatus. Plant Sci. 160, 291-299. doi: 10.1016/S0168-9452(00) 00392-7

Palma, J. M., Jiménez, A., Sandalio, L. M., Corpas, F. J., Lundqvist, M., Gómez, M., et al. (2006). Antioxidative enzymes from chloroplasts, mitochondria, and peroxisomes during leaf senescence of nodulated pea plants. J. Exp. Bot. 57, 1747-1758. doi: 10.1093/jxb/erj191

Peeva, V. N., Tóth, S. Z., Cornic, G., and Ducruet, J. M. (2012). Thermoluminescence and P700 redox kinetics as complementary tools to investigate the cyclic/chlororespiratory electron pathways in stress conditions in barley leaves. Physiol. Plant. 144, 83-97. doi: 10.1111/j.1399-3054.2011.01519.x

Reiter, R. J., Tan, D.-X., Zhou, Z., Cruz, M. H. C., Fuentes-Broto, L., and Galano, A. (2015). Phytomelatonin: assisting plants to survive and thrive. Molecules 20, 7396-7437. doi: 10.3390/molecules20047396

Robinson, S. P., Downton, W. J. S., and Millhouse, J. A. (1983). Photosynthesis and ion content of leaves and isolated chloroplasts of salt-stressed spinach. Plant Physiol. 73, 238-242. doi: 10.1104/pp.73.2.238

Sarrou, E., Therios, I., and Dimassi-Theriou, K. (2014). Melatonin and other factors that promote rooting and sprouting of shoot cuttings in Punica granatum cv. Wonderful. Turk. J. Botany 38, 293-301. doi: 10.3906/bot-1302-55

Sato, Y., Masuta, Y., Saito, K., Murayama, S., and Ozawa, K. (2011). Enhanced chilling tolerance at the booting stage in rice by transgenic overexpression of the ascorbate peroxidase gene, OsAPXa. Plant Cell Rep. 30, 399-406. doi: 10.1007/s00299-010-0985-7

Sergiev, I., Alexieva, V., and Karanov, E. (1997). Effect of spermine, atrazine and combination between them on some endogenous protective systems and stress markers in plants. Compt. Rend. Acad. Bulg. Sci. 51, 121-124.

Shao, Q., Wang, H., Guo, H., Zhou, A., Huang, Y., Sun, Y., et al. (2014). Effects of shade treatments on photosynthetic characteristics, chloroplast ultrastructure, and physiology of Anoectochilus roxburghii. PLoS ONE 9:e85996. doi: 10.1371/ journal.pone.0085996

Shi, H., Tan, D. X., Reiter, R. J., Ye, T., Yang, F., and Chan, Z. (2015). Melatonin induces class A1 heat-shock factors (HSFA1s) and their possible involvement of thermotolerance in Arabidopsis. J. Pineal Res. 58, 335-342. doi: 10.1111/jpi. 12219

Shu, S., Yuan, L.-Y., Guo, S.-R., Sun, J., and Yuan, Y.-H. (2013). Effects of exogenous spermine on chlorophyll fluorescence, antioxidant system and ultrastructure of chloroplasts in Cucumis sativus L. under salt stress. Plant Physiol. Biochem. 63, 209-216. doi: 10.1016/j.plaphy.2012.11.028

Shuming, H., Qiang, D., Qing-yun, L., Xue, Z., and Bo, G. (2012). Effects of exogenous putrescine(Put) and spermine(Spm) on membrane-lipid peroxidation of strawberry (Fragaria $\times$ ananassa) leaves under $\mathrm{NaCl}$ stress. J. Anhui Agric. Sci. 40, 989-1991. doi: 10.13989/j.cnki.0517-6611.2012.04.210

Tan, D.-X., Manchester, L. C., Di Mascio, P., Martinez, G. R., Prado, F. M., and Reiter, R. J. (2007a). Novel rhythms of N1-acetyl-N2-formyl5-methoxykynuramine and its precursor melatonin in water hyacinth: importance for phytoremediation. FASEB J. 21, 1724-1729. doi: 10.1096/fj.06$7745 \mathrm{com}$

Tan, D.-X., Manchester, L. C., Helton, P., and Reiter, R. J. (2007b). Phytoremediative capacity of plants enriched with melatonin. Plant Signal. Behav. 2, 514-516. doi: 10.4161/psb.2.6.4639

Thayer, W. S. (1990). Superoxide-dependent and superoxide-independent pathways for reduction of nitroblue tetrazolium in isolated rat cardiac myocytes. Arch. Biochem. Biophys. 276, 139-145. doi: 10.1016/0003-9861(90) 90020-Y

Urata, Y., Honma, S., Goto, S., Todoroki, S., Iida, T., Cho, S., et al. (1999). Melatonin induces gamma-glutamylcysteine synthetase mediated by activator protein-1 in human vascular endothelial cells. Free Radic. Biol. Med. 27, 838847. doi: 10.1016/S0891-5849(99)00131-8

Von Caemmerer, S. V., and Farquhar, G. (1981). Some relationships between the biochemistry of photosynthesis and the gas exchange of leaves. Planta 153, 376-387. doi: 10.1007/BF00384257

Wang, J., Zeng, Q., Zhu, J., Liu, G., and Tang, H. (2013). Dissimilarity of ascorbateglutathione (AsA-GSH) cycle mechanism in two rice ( Oryza sativa L.) cultivars under experimental free-air ozone exposure. Agric. Ecosyst. Environ. 165, 39-49. doi: 10.1016/j.agee.2012.12.006

Wang, L., Liu, J., Wang, W., and Sun, Y. (2016). Exogenous melatonin improves growth and photosynthetic capacity of cucumber under salinity-induced stress. Photosynthetica 54, 19-27. doi: 10.1007/s11099-015-0140-3

Wang, P., Yin, L., Liang, D., Li, C., Ma, F., and Yue, Z. (2012). Delayed senescence of apple leaves by exogenous melatonin treatment: toward regulating the ascorbate-glutathione cycle. J. Pineal Res. 53, 11-20. doi: 10.1111/j.1600-079X. 2011.00966.x

Wei, W., Li, Q.-T., Chu, Y.-N., Reiter, R. J., Yu, X.-M., Zhu, D.-H., et al. (2014). Melatonin enhances plant growth and abiotic stress tolerance in soybean plants. J. Exp. Bot. 66, 695-707. doi: 10.1093/jxb/eru392

Xi, Z., Wang, Z., Fang, Y., Hu, Z., Hu, Y., Deng, M., et al. (2013). Effects of 24epibrassinolide on antioxidation defense and osmoregulation systems of young grapevines (V. vinifera L.) under chilling stress. Plant Growth Regul. 71, 57-65. doi: 10.1007/s10725-013-9809-4

Xia, X. J., Gao, C. J., Song, L. X., Zhou, Y. H., Shi, K., and Yu, J. Q. (2014). Role of $\mathrm{H} 2 \mathrm{O} 2$ dynamics in brassinosteroid-induced stomatal closure and opening in Solanum lycopersicum. Plant Cell Environ. 37, 2036-2050. doi: 10.1111/pce. 12275

Xu, P. L., Guo, Y. K., Bai, J. G., Shang, L., and Wang, X. J. (2008). Effects of long-term chilling on ultrastructure and antioxidant activity in leaves of two cucumber cultivars under low light. Physiol. Plant. 132, 467-478. doi: 10.1111/ j.1399-3054.2007.01036.x

Yang, Y., Chang, D., Wang, Y., and Zhang, F. C. (2015). Effects of exogenous JA and MeJA on seed germination and seeding physiological characteristics of Gossypium hirsutum under salt stress. Seed 34, 8-18. doi: 10.16590/J.cnki.10014705.2015.01.045 
Yuan, L., Shu, S., Sun, J., Guo, S., and Tezuka, T. (2012). Effects of 24epibrassinolide on the photosynthetic characteristics, antioxidant system, and chloroplast ultrastructure in Cucumis sativus L. under Ca (NO3) 2 stress. Photosynth. Res. 112, 205-214. doi: 10.1007/s11120-012-9774-1

Zhan, G.-M., Li, R.-J., Hu, Z.-Y., Liu, J., Deng, L.-B., Lu, S.-Y., et al. (2014). Cosuppression of RBCS3B in Arabidopsis leads to severe photoinhibition caused by ROS accumulation. Plant Cell Rep. 33, 1091-1108. doi: 10.1007/ s00299-014-1597-4

Zhang, D., Ren, L., Chen, G. Q., Zhang, J., Reed, B. M., and Shen, X. H. (2015a). ROS-induced oxidative stress and apoptosis-like event directly affect the cell viability of cryopreserved embryogenic callus in Agapanthus praecox. Plant Cell Rep. 34, 1499-1513. doi: 10.1007/s00299-015-1802-0

Zhang, N., Sun, Q., Zhang, H., Cao, Y., Weeda, S., Ren, S., et al. (2015b). Roles of melatonin in abiotic stress resistance in plants. J. Exp. Bot. 66, 647-656. doi: $10.1093 / \mathrm{jxb} / \mathrm{eru} 336$

Zhang, N., Zhao, B., Zhang, H. J., Weeda, S., Yang, C., Yang, Z. C., et al. (2013). Melatonin promotes water-stress tolerance, lateral root formation, and seed germination in cucumber (Cucumis sativus L.). J. Pineal Res. 54, 15-23. doi: 10.1111/j.1600-079X.2012.01015.x

Zhang, Z., Jia, Y., Gao, H., Zhang, L., Li, H., and Meng, Q. (2011). Characterization of PSI recovery after chilling-induced photoinhibition in cucumber (Cucumis sativus L.) leaves. Planta 234, 883-889. doi: 10.1007/s00425-0111447-3
Zhao, Y., Qi, L. W., Wang, W. M., Saxena, P. K., and Liu, C. Z. (2011). Melatonin improves the survival of cryopreserved callus of Rhodiola crenulata. J. Pineal Res. 50, 83-88. doi: 10.1111/j.1600-079X.2010.00817.x

Zhou, Y., Yu, J., Huang, L., and Nogués, S. (2004). The relationship between CO2 assimilation, photosynthetic electron transport and water-water cycle in chillexposed cucumber leaves under low light and subsequent recovery. Plant Cell Environ. 27, 1503-1514. doi: 10.1111/j.1365-3040.2004.01255.x

Conflict of Interest Statement: The authors declare that the research was conducted in the absence of any commercial or financial relationships that could be construed as a potential conflict of interest.

The reviewer QW and handling Editor declared their shared affiliation, and the handling Editor states that the process nevertheless met the standards of a fair and objective review.

Copyright (c) 2016 Zhao, Ye, Wang, Zhou, Yang, Wang, Cao and Zou. This is an open-access article distributed under the terms of the Creative Commons Attribution License (CC BY). The use, distribution or reproduction in other forums is permitted, provided the original author(s) or licensor are credited and that the original publication in this journal is cited, in accordance with accepted academic practice. No use, distribution or reproduction is permitted which does not comply with these terms. 